\title{
Relative importance of perch and facilitative effects on nucleation in tropical woodland in Malawi
}

\author{
$\operatorname{AUTHOR}(\mathrm{S})$ : \\ Fujita, Tomohiro
}

CITATION:

Fujita, Tomohiro. Relative importance of perch and facilitative effects on nucleation in tropical woodland in Malawi. Acta Oecologica 2016, 70: 45-52

\section{ISSUE DATE:}

2016-01

URL:

http://hdl.handle.net/2433/203605

\section{RIGHT:}

(c) 2015. This manuscript version is made available under the CC-BY-NC-ND 4.0 license

http://creativecommons.org/licenses/by-nc-nd/4.0/; The full-text file will be made open to the public on 1 January 2018 in accordance with publisher's 'Terms and Conditions for Self-Archiving'.; This is not the published version. Please cite only the published version.; この論文は出版社版でありません。引用の際には出版社版をご確認ご利用ください。 
Original article

\title{
Relative importance of perch and facilitative effects on nucleation in tropical woodland in Malawi ${ }^{\text {th }}$
}

Tomohiro Fujita a, b, *

tfujita0727@gmail.com

aGraduate School of Asian and African Area Studies, Kyoto University, Kyoto

606-8502, Japan

'Graduate School of Letters, Kyoto University, Kyoto 606-8501, Japan

*Graduate School of Asian and African Area Studies, Kyoto University, Kyoto

606-8502, Japan.

«Tomohiro Fujita obtained the funding, designed the study, collected data, performed analyses and wrote the manuscript.

\begin{abstract}
Individual trees in open vegetation such as woodlands can act as "nuclei" for the colonization of forest tree species, which consequently lead to the formation of forest patches. This phenomenon is known as nucleation. The mechanism of nucleation is generally attributed to two factors: trees provide perches for frugivores that increase seed deposition (perch effect), and tree crowns ameliorate environmental conditions, which improves seedling establishment (facilitative effect). Few studies have attempted to distinguish the relative importance of these two factors. In this study, I separated these two effects in a woodland in northern Malawi. I chose Ficus natalensis as a potential nuclei tree because large individuals of this species are commonly located at the center of forest patches within open woodland at the study site. I monitored several environmental variables, seedling survival, seedling composition, and seed rain at three microsites: underF. natalensis, under Brachystegia floribunda (a dominant woodland species), and in open sites. Both tree species provided similar favorable conditions for the establishment of forest species compared to open sites. Thus, the survival of forest tree seedlings under $F$. natalensis and $B$. floribunda was similar, and substantially higher than seedling survival in open sites. However, communities of naturally occurring seedlings differed significantly between $F$. natalensis and B. floribunda. These results indicate that the facilitative effect alone cannot explain the nucleation pattern. I attribute this result to the perch effect of F.natalensis because the forest seedling species recorded under F.natalensis reportedly have small, brightly colored diaspores, which
\end{abstract}


are indicative of dispersal by birds. Seed deposition of forest species underF. natalensis was significantly higher than that under B. floribunda or in open sites. My findings reinforce the idea that trees will lead to nucleation when they enhance seed deposition and have a positive effect on the post-dispersal stage.

Keywords: Facilitation; Ficus; Forest-savanna boundary; Frugivore; Nurse plant; Seed dispersal

\section{Introduction}

Open vegetation such as grasslands and woodland areas intermingled with closed-canopy forests are common in many tropical regions. Because these tropical forest/open vegetation mosaics cover such large areas, changes to their vegetative structure and composition, and the resulting feedbacks, could have significant implications for biodiversity and the carbon cycle (Mitchard et al., 2009). Although there has been a major loss of forest area caused by logging and other factors, recent studies have also documented the expansion of tropical forests into open vegetation areas in many parts of the world (Puyravaud et al., 2003; Favier et al., 2004; Bowman et al., 2010). Understanding the processes and mechanisms of forest expansion has broad implications for biodiversity conservation and the management of forest/open vegetation mosaics.

The occurrence of individual trees in open vegetation can act as nuclei for the colonization of forest tree species. This process, known as nucleation (Yarranton and Morrison, 1974), can aid colonization of forest tree species, leading to the formation of forest patches. The mechanism of nucleation is generally explained by two different ecological processes (Corbin and Holl, 2012; Zahawi et al., 2013): the perch effect and the facilitative effect. By providing perch sites and fruit, trees in open areas can attract frugivores from nearby forests, and this increases the seed rain of animal-dispersed forest species under their crowns. Additionally, trees in open areas can facilitate forest tree establishment by mitigating stressful environmental conditions, such as high irradiance, high temperatures, and soil water deficits.

Many studies have attempted to verify the mechanisms of nucleation by comparing seedling composition under putative nucleus trees to that in open matrix (e.g., Duarte et al., 2006; Carlucci et al., 2011; Arantes et al., 2014; Fujita and Mizuno, 2015). For instance, Duarte et al. (2006) found more seedlings of forest species established under crowns of Araucaria angustifolia than in open matrix in southern 
Brazilian grasslands. They attributed this result to the perch effect, given that most seedlings under the crowns had vertebrate-dispersed diaspores. They also suggested that $A$. angustifolia facilitated the establishment of forest species by ameliorating microclimatic conditions such as air humidity and soil water content under the crowns. Other studies have drawn similar conclusions (e.g., Carlucci et al., 2011; Arantes et al., 2014). However, few studies have attempted to separate the relative importance of perch and facilitative effects in the nucleation process (but see Pausas et al., 2006; Albornoz et al., 2013). Nucleation might be generated by either perch or facilitative effect. For instance, nucleation may commence if seeds of forest species are disproportionally deposited under crowns that have neutral effects on post dispersal fate. Alternatively, if the seeds are randomly distributed in space but trees in open areas provide suitable conditions for forest tree species beneath the crowns, nucleation may also occur. Indeed, Vieira et al. (2013) found more seedlings from non-animal dispersed species under Combretum leprosum, suggesting that the facilitative effect is the main process driving nucleation in southern Brazilian grasslands. Separating the role of perch and facilitative effects is necessary to fully understand the mechanism of the nucleation.

Trees in the genus Ficus (Moraceae) make effective nuclei because their syconia attract many frugivores, and the microhabitat under their dense crowns is suitable for the establishment of forest trees (Slocum and Horvitz, 2000; Slocum, 2001; Schlawin and Zahawi, 2008). In northern Malawi (southeast Africa), circular patches of forest occur within tropical woodland, with large fleshy-fruited trees, especially Ficus natalensis, located at their centers (Fujita, 2014). These circular patches are a common feature of nucleated forest patches, rather than fragmented forests (Favier et al., 2004; Duarte et al., 2007). Thus, this region is a suitable field site for testing the nucleation process.

The aim of this study was to elucidate the mechanisms of nucleation by separating the importance of perch and facilitative effects. To address this topic, I compared seedling compositions among three microsites within tropical woodland: under F. natalensis, under Brachystegia floribunda Benth., and in open microsites. F. natalensis and $B$. floribunda have dense crowns that can provide suitable habitat for the establishment of forest tree species. However, B.floribunda bears dry pods that are explosively dispersed (Chidumayo and Frost, 1996) and do not attract frugivores, making it unlikely to have a perch effect on seed deposition. If seedling abundance of forest species is higher under F.natalensis than under B. floribunda or in open microsites, and if the established seedlings are primarily animal-dispersed species, it 
suggests the importance of perch effect during nucleation. In contrast, if the abundance and composition of seedlings do not differ under F. natalensis and B. floribunda, it would suggest that facilitation is the driving force. To address these predictions, I (1) analyzed the environmental conditions in the three microsites, (2) monitored seedling survival of Syzygium guineense ssp. afromontanum F. White (a forest tree species) in the three microsites for 2.5 years, (3) analyzed the seedling composition in the three microsites, (4) quantified the seed rain of $S$. guineensessp. afromontanum in the three microsites and (5) observed animal visitors at fruiting F. natalensis trees.

\section{Materials and methods 2.1 Study area}

The study was conducted in northern Malawi (southeastern Africa). In southeastern Africa, approximately 2.7 million $\mathrm{km}^{2}$ of land are covered with tropical woodland called miombo woodland, which consist of leguminous species in three closely related genera: Brachystegia, Julbernardia and Isoberlinia(Fabaceae subfamily Caesalpinioideae; Campbell et al., 1996). This region also contains patchy montane rainforest, which differs from miombo woodland in floristic composition and structure (White et al., 2001). The distributions of miombo woodlands and forest have shifted over wide areas of landscape (Vincens et al., 2003). Ekblom (2008) suggested that climatic conditions after 1850 AD have been favorable for forest expansion.

For these experiments, I selected an area typical to this region in a rural zone managed by the village of Ntchuka ( $\left.10^{\circ} 58^{\prime} \mathrm{S}, 34^{\circ} 04^{\prime} \mathrm{E}\right)$ on the north Vipya Plateau in northern Malawi (a map of the study area is available, see Fujita, 2014). Mean annual rainfall on the north Vipya Plateau exceeds $1270 \mathrm{~mm}$, with most rainfall occurring during the wet season between December and April (Chapman, 1970). The bedrock of the Vipya Plateau is composed of undifferentiated basement complex rocks, primarily gneisses (Chapman, 1970). Soil of the study area is a well-drained red and sandy clay loam. The study site is predominantly covered by miombo woodland, although some montane rainforest occurs on mountain crests (>1800 m asl), in valleys, and in several circular forest patches $\left(\sim 10-1800 \mathrm{~m}^{2}\right)$ on mountainous slopes $(1700-1800 \mathrm{~m}$ asl). With the exception of montane rainforests, most of the land is burned by humans approximately every 2-3 years during the dry season (September-December). Fires are set to clear footpaths, because overgrown paths are difficult to traverse and pose a risk of hiding snakes. Montane rainforests are typically less flammable due to their dense 
canopy that excludes grasses and maintains a more humid understory (Hoffmann et al., 2012a). Therefore, fire is unlikely to penetrate far into the forest. Antelopes such as the common duiker (Sylvicapra grimmia) were seen at the study site. Few trees are harvested from this area because it is located far from local villages.

\subsection{Study species}

F.natalensis is a medium to tall tree species (up to $30 \mathrm{~m}$ ) distributed in eastern and southern Africa. In the study area, it grows primarily in miombo woodland and is also located at the center of montane rainforest patches. Its syconia $(1.1 \pm 0.1 \times 1.0 \pm 0.1 \mathrm{~cm}, \quad \mathrm{n}=10)$ change from green to yellowish during ripening. F.natalensis has two periods of fruit ripening each year: August-October and January-April. Fruit bats and birds are potential seed dispersers (McCarthy et al., 1998).

Brachystegia floribunda (Fabaceae, Caesalpinioideae) is a medium to tall tree $(\leq 20 \mathrm{~m})$ that is the dominant species in the miombo woodland of northern Malawi, where this study was conducted. The tree produces woody pods (up to $12.5 \times 4.0 \mathrm{~cm}$ ) from October-January; the pods explosively disperse their seeds (Chidumayo and Frost, 1996).

\subsection{Data collection}

\subsubsection{Environmental conditions}

To examine whether F. natalensis and B. floribunda have similar facilitative effects on the establishment of forest tree species, I monitored environmental variables in three microsites: under F. natalensis, under B.floribunda, and in open microsites. I selected eight $F$. natalensis individuals in miombo woodland that were $>50 \mathrm{~m}$ from montane rainforest or forest patches. The mean distance between $F$. natalensis trees and forest or forest patches was $169 \mathrm{~m}$ (range $=56-307 \mathrm{~m}$ ). I also selected $B$. floribunda trees and open microsites (3-m radius lacking both trees and canopy cover over $5 \mathrm{~cm}$ in dbh) within $50 \mathrm{~m}$ of the F. natalensis trees. I haphazardly chose eight $B$. floribunda individuals with heights and diameters at breast height (dbh) similar to those of the F. natalensisindividuals. F.natalensis and B. floribunda did not exhibit canopy overlap.

I measured the following microhabitat variables: canopy openness, air temperature, relative humidity, soil water content, and the proportion of grass cover. To estimate canopy openness, I took four hemispherical canopy photographs in February 2012 (after the leaves were fully expanded) at each microsite at a height of $1 \mathrm{~m}$ above the ground using a fish-eye lens (Raynox DCR-CF; Yoshida Industry, Tokyo, Japan). The pictures were taken at the midpoint of the crown radius in each cardinal direction 
from the trunk. At the open microsite, the pictures were taken in each cardinal direction at $1 \mathrm{~m}$ from the center of the plot. I then used gap light analyzer software (Frazer et al., 1999) to calculate canopy openness. The overall canopy openness at each microsite was calculated as the mean of the four values. Air temperature and relative humidity were measured every 15 min over three days using a data logger (Ondotori RH TR72U, T and D, Matsumoto, Japan) placed $1 \mathrm{~m}$ from the trunk, or in the center of the open microsite. The measurements were made during the dry season (September 2012). Soil water content was measured at 12-cm depth using time domain reflectometry TDR probes (Hydrosense; Campbell Scientific, Townsville, Australia) at the same location where the canopy photographs were taken. The overall soil water content at each microsite was calculated as the mean of the four values. The measurements were made during the dry season (September 2012) and the rainy season (March 2013). In September 2012 before fires occurred, I visually estimated the proportion of grass cover in four $1 \times 1$-m quadrats (same locations as the canopy photographs), and calculated the grass cover at each site as the mean of these four quadrats.

\subsubsection{Seedling survival of a forest species}

To examine the facilitative effect of trees on the establishment of forest tree species, I monitored seedling survival of $S$. guineense ssp. afromontanum in the three microsites. Syzygium guineense ssp. afromontanum is endemic to montane rainforest and is a common species in montane rainforests on the Vipya Plateau (White et al., 2001). This species is a medium to tall tree (up to $30 \mathrm{~m}$ ) that bears purple berries from January to March, with a mean fruit size of $1.6 \times 1.4 \mathrm{~cm}(\mathrm{n}=6)$. In January 2012, I planted S. guineense ssp. afromontanum seeds in a nursery. Four weeks after they developed their first true leaves, I transplanted the seedlings into the three field microsites. Under each tree, and in each open microsite, I planted 16 seedlings, separated by $50 \mathrm{~cm}$ in a $4 \times 4$ grid (384 seedlings total). Seedlings were watered immediately after transplanting, but no additional treatments were applied. Initial survival was determined 1 week after planting and seedlings that had died due to transplant shock were replaced. The seedling survival was then monitored at approximately 1, 6, 7, 10, 19 and 31 months following planting.

\subsubsection{Seedling composition}

In August 2011, prior to the fire season, I measured seedling composition using four $2 \times 5$-m quadrats placed in the four cardinal directions around each tree trunk, or around the center of the plot in the open microsites. I counted all seedlings (0.2-1 m high) in each quadrat and pooled these data for each plot. Plant specimens were 
identified at the National Herbarium and Botanical Gardens of Malawi. I then determined the preferred habitat of each species from the literature (Friis, 1992; White et al., 2001).

\subsubsection{Seed rain of Syzygium guineense ssp. afromontanum}

I quantified seed rain of $S$. guineense ssp. afromontanum from January to March 2012 using seed traps. The traps were $70 \times 70 \mathrm{~cm}$ of fine-mesh net secured to the ground, with 5-cm-high sides to prevent collected seed from washing away. Three seed traps were placed $1 \mathrm{~m}$ from the base of each trunk or $1 \mathrm{~m}$ from the center of the open microsites, for a total of 72 seed traps across all plots. The direction of the first quadrat was determined randomly, and the others were placed at $120^{\circ}$ and $240^{\circ}$ from the first. Each microsite was visited twice per week, and seeds were collected and counted. Seeds from the three traps in a plot were combined for analysis.

\subsubsection{Tree observations}

Focal observations of four fruiting $F$. natalensis trees in miombo woodlands were carried out from January to March 2011 to estimate the potential dispersers of forest tree species into miombo woodlands. Observations were conducted in three time blocks: 05h30-08h30, 08h30-12h30 and 12h30-15h30. Each tree was observed twice for each time block, one time block per day, and not on successive days. The total observation time for all four trees was 80 h. Each tree was observed from a distance of 20 m using binoculars. For all animal visitors, I recorded the duration of their stay in the tree and their behavior (i.e., whether the animal consumed fruit, fed on arthropods, or just perched on the tree). I classified a behavior as "feeding" when an animal fed on syconia or insects that were visible to the observer. When the animal under observation fed on neither syconia nor insects but perched in the tree, I classified the behavior as"perch". When two or more individuals of the same species were present within the branch structure of a single tree, I was unable to accurately collect data on all of them. Therefore, I collected data for only one focal individual. Bird and animal species were identified with reference to Kingdon (1974), Fry and Keith (1988), Fry et al. (1988), Keith et al. (1992), Urban et al. (1997), Fry et al. (2004) andDowsett-Lemaire and Dowsett (2006). Based on these sources, I classified each bird and animal species into forest, forest/woodland or woodland species.

\subsection{Data analysis}

Statistical analyses were conducted using $\mathrm{R}$ software ver. 2.14 .0 (R Development Core Team; http://www.r-project.org/). Environmental variables were tested for normality (Kolmogorov_-Smirnov's test) and homogeneity of variances 
(Bartlett's test) prior to statistical analysis. When the data were normal and homoscedastistic, I used a one-way ANOVA followed by Tukey's multiple comparison test (when appropriate) to detect significant differences in the environmental variables among microsites. If the data did not fit the assumptions of inferential parametric statistics, I used the non-parametric Kruskal_-Wallis test followed by the Steel_-Dwass multiple comparisons test.

The final percent survival of $S$. guineense ssp. afromontanum was analyzed using GLM with a binomial log-link function. Tukey's multiple comparison tests were used to detect differences in seedling survival among microsites. The tests were conducted with the glht function in the R multicomp package.

Non-metric multi-dimensional scaling (NMDS) analyses, based on the BrayCurtis dissimilarity index, were performed to visualize differences in seedling composition among microsites. Furthermore, to investigate whether differences in species composition among microsites were significant, I performed a PERMANOVA using the metaMDS function in the $\mathrm{R}$ vegan package.

The species that were typical of the different microsites were determined using the indicator species analysis (Dufrêne and Legendre, 1997) available in the labdsv package of $\mathrm{R}$. This approach calculates an index (Indval) that clearly measures the fidelity of a taxon to a specific range of different habitat types. These indices were tested for statistical significance $(P \leq 0.05)$ against random expectations using a Monte Carlo permutation with 1000 replicates.

The numbers of forest species seedlings and the seed rain counts for S.guineense ssp. afromontanum were discrete variables(i.e., not continuous). These data did not fit the assumption of normality and were therefore analyzed using the nonparametric Kruskal_-Wallis test followed by the Steel_-Dwass multiple comparisons test to detect significant differences among microsites.

\section{Results}

\subsection{Environmental characterization of the microsites}

Although the soil water content did not vary significantly among the microsites, other variables did (Table 1). Canopy openness, mean air temperature and the proportion of grass cover were significantly lower under F. natalensis and under $B$. floribunda than in open sites. However, the values for these variables under F. natalensis were not significantly different from those under B.floribunda. The 
air humidity under $F$. natalensis and under $B$. floribunda were significantly higher than those in open sites, but did not differ significantly from one another.

Table 1 Environmental conditions measured among three microsites (means \pm SE) in a miombo woodland in northern Malawi.

\begin{tabular}{|c|c|c|c|}
\hline Dependent variables & Under Ficus natalensis & Under Brachystegia floribunda & Open \\
\hline Canopy openness (\%) & $11.3 \pm 1.0 a$ & $16.3 \pm 2.1 a$ & $54.8 \pm 3.4 b$ \\
\hline $\mathrm{Ta}\left({ }^{\circ} \mathrm{C}\right)$ & $21.6 \pm 0.6 a$ & $21.6 \pm 0.7 a$ & $24.8 \pm 1.2 b$ \\
\hline $\mathrm{RH}(\%)$ & $50.4 \pm 1.8 a$ & $49.8 \pm 2.6 a$ & $41.4 \pm 2.4 b$ \\
\hline Grass cover (\%) & $19.5 \pm 1.9 a$ & $35.0 \pm 6.2 a$ & $58.8 \pm 3.3 b$ \\
\hline SWC (rainy season) (\%) & $29.6 \pm 1.4$ & $30.4 \pm 1.5$ & $30.6 \pm 1.3$ \\
\hline SWC (dry season) (\%) & $3.3 \pm 0.5$ & $3.0 \pm 0.6$ & $2.9 \pm 0.5$ \\
\hline
\end{tabular}

See the text for microsite definitions. Variables: Ta, mean air temperature; RH, relative humidity; SWC, soil water content. Summary statistics of tests for significant differences in the dependent variables among the independent variables: canopy openness, $\mathrm{x} 2=16.81, \mathrm{df}=2, \mathrm{p}<0.001 ; \mathrm{Ta}, \mathrm{F}=25.32, \mathrm{df}=2$, $\mathrm{p}<0.0001 ; \mathrm{RH}, \mathrm{F}=37.15, \mathrm{df}=2, \mathrm{p}<0.0001$; grass cover, $\mathrm{x} 2=14.95, \mathrm{df}=2, \mathrm{p}<0.001$; SWC (rainy season), $\mathrm{F}=0.14, \mathrm{df}=2, \mathrm{p}=0.87$; SWC (dry season), $\mathrm{F}=0.20, \mathrm{df}=2, \mathrm{p}=0.82$. Different lower case letters following numerical values indicate significant pairwise differences ( $\alpha=0.05$, Tukey's test or the Steel-Dwass test) in the same row.

\subsection{Seedling survival}

Of the S. guineense ssp. afromontanum seedlings initially planted, $41.7 \%$ survived until the end of the experiment. Seedling survival at the end of the experiment was significantly affected by microsite (Fig. 1). Seedling survivals under F. natalensis and under B. floribunda were significantly higher than the survival in open sites. However, the value under F. natalensis was not significantly different from those under $B$. floribunda. The cumulative survival of seedlings under $F$. natalensis and $B$. floribunda was sixfold higher than in open sites. 


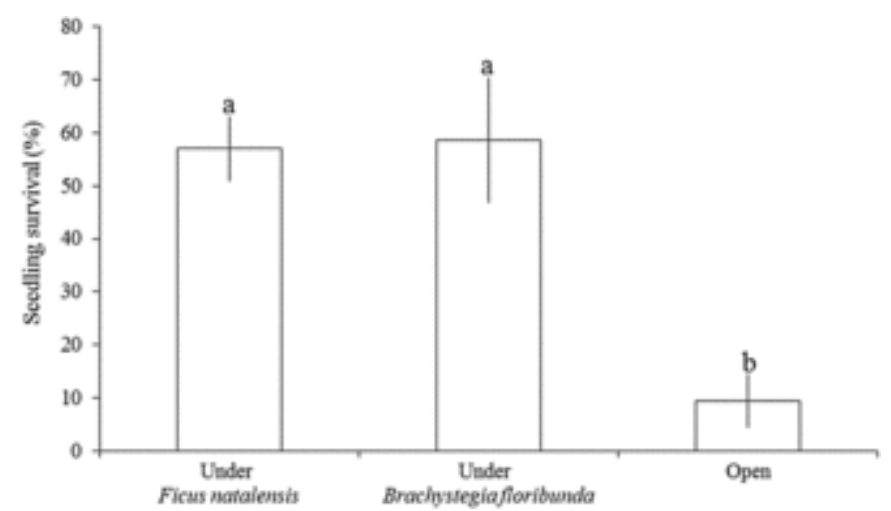

Fig. 1 Mean seedling survival of Syzygium guineense ssp. afromontanum ( $\pm 1 \mathrm{SE}$ ) in three microsite environments in a miombo woodland in northern Malawi. Seedling survival ( $\mathrm{n}=384$ ) was measured from February 2012 to August 2014. Means followed by the same letter are not significantly different $(P>0.05)$ among microsites based on Tukey's post hoc tests.

\subsection{Composition of seedling communities}

In total, I found 401 seedlings from 39 tree species. The NMDS (stress $=0.12$ ) showed that seedling composition differed among the three microsites (Fig. 2). Seedling composition under $F$. natalensis differed significantly from the seedling composition under $B$. floribunda (PERMANOVA, pseudo- $F=3.24, P<0.01$ ) and in open sites (PERMANOVA, pseudo- $F=5.48, P<0.01$ ). In contrast, there was no statistical difference in the seedling communities underB. floribunda and those in open sites (PERMANOVA, pseudo- $F=1.14, \mathrm{P}=0.34$ ). Of the seedlings counted, 152 individuals (38\%) from 18 species were characterized as forest or forest-related taxa (forest/woodland species; Table 2). Most of these seedlings (93\%) were found under F. natalensis. The seedling numbers of forest and forest-related species were significantly greater under F.natalensis than under B. floribunda (Steel-Dwass multiple comparisons test, $\mathrm{t}=3.34, P<0.01$ ) or at open sites (Steel-Dwass multiple comparisons test, $\mathrm{t}=3.59, P<0.01)$. Diaspores of these species possessed characteristics associated with vertebrate dispersal (Table 2). Six “indicator species” were identified for F.natalensis sites: Mystroxylon aethiopicum (Thunb.) Loes. (Celastraceae),Diospyros whyteana (Hiern) F. White (Ebenaceae), Apodytes dimidiata E Mey. (Icacinaceae), S. guineense ssp. afromontanum, Prunus africana (Hook. f.) Kalkman (Rosaceae), and Rhus longipes Engl. (Anacardiaceae). All of these, with the exception of $R$. longipes, are forest or forest-related species (Table 2). In contrast, I was unable to identify any specific indicator species under B.floribunda or for open sites. 


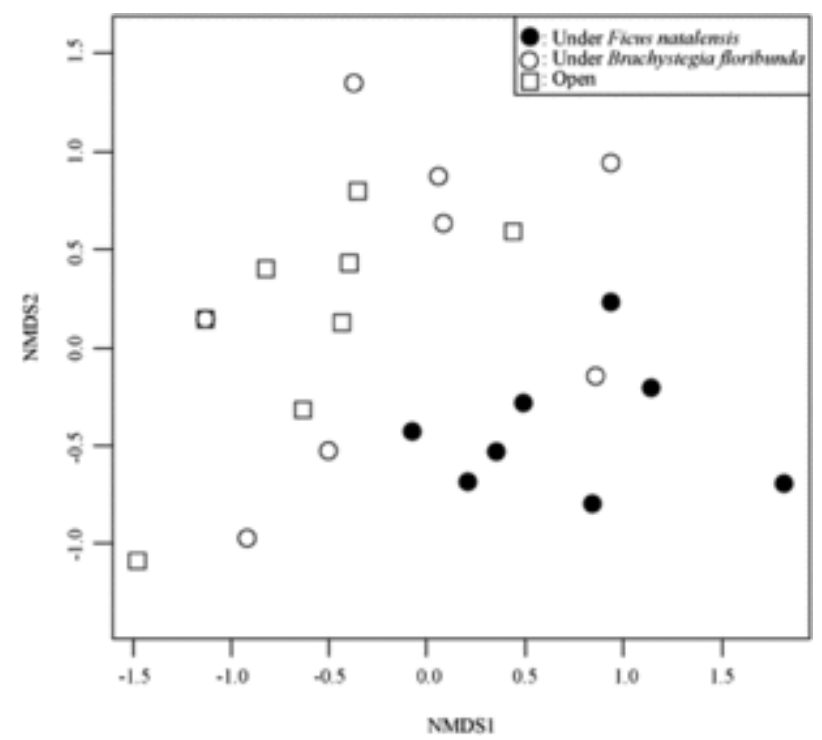

Fig. 2 Non-metric multidimensional scaling ordination of seedling compositions for three microsite classes in a miombo woodland in northern Malawi. Dissimilarities between sites were calculated using the Bray_-Curtis distance based on counts at each site. 
Table 2 List of woody plant seedling at three microsites in northern Malawi.

\begin{tabular}{|c|c|c|c|c|c|c|c|c|}
\hline \multirow[t]{2}{*}{ Species name } & \multirow[t]{2}{*}{ Family } & \multirow{2}{*}{$\begin{array}{l}\text { Fruit } \\
\text { size } \\
(\mathrm{mm})\end{array}$} & \multirow{2}{*}{$\begin{array}{l}\text { Fruit } \\
\text { color }\end{array}$} & \multirow{2}{*}{$\begin{array}{l}\text { Mode of } \\
\text { seed } \\
\text { dispersal }\end{array}$} & \multirow[t]{2}{*}{ Habitat } & \multicolumn{3}{|c|}{ No. of seedlings } \\
\hline & & & & & & Fn & $B f$ & Open \\
\hline Rhus longipesEngl. ${ }^{a}$ & Anacardiaceae & $6 \times 5$ & brown & animal & woodland & 22 & 1 & 0 \\
\hline $\begin{array}{l}\text { Ozoroa insignisssp. reticulata(Baker } \\
\text { f.) J.B. Gillett }{ }^{b}\end{array}$ & Anacardiaceae & unknown & black & animal & woodland & 0 & 0 & 1 \\
\hline Cussonia arboreaHochst. ex A. Rich. ${ }^{a}$ & Araliaceae & 5 in dia. & purple & animal & woodland & 5 & 4 & 1 \\
\hline Cussonia spicataThunb. ${ }^{\text {a }}$ & Araliaceae & $7 \times 7$ & purple & animal & for./woodl. & 13 & 0 & 0 \\
\hline Schefflera umbellifera(Sond.) Baill. ${ }^{a}$ & Araliaceae & 3 in dia. & red & animal & forest & 3 & 0 & 0 \\
\hline Tecoma nyassaeOliv. ${ }^{\mathrm{b}}$ & Bignoniaceae & unknown & unknown & unknown & woodland & 0 & 1 & 0 \\
\hline Brachystegia floribundaBenth. ${ }^{\mathrm{a}}$ & Caesalpinioideae & - & - & explosive & woodland & 17 & 21 & 40 \\
\hline Brachystegia boehmii Taub. ${ }^{a}$ & Caesalpinioideae & - & - & explosive & woodland & 0 & 3 & 10 \\
\hline $\begin{array}{l}\text { Mystroxylon } \\
\text { aethiopicum(Thunb.) Loes. }{ }^{c}\end{array}$ & Celastraceae & $16 \times 15$ & red & animal & for./woodl. & 14 & 0 & 0 \\
\hline $\begin{array}{l}\text { Parinari curatellifoliaPlanch. ex } \\
\text { Benth. }\end{array}$ & Chrysobalanaceae & $50 \times 20$ & yellow & animal & woodland & 0 & 0 & 3 \\
\hline Monotes africanus A. DC. ${ }^{\text {a }}$ & Dipterocarpaceae & - & - & wind & woodland & 0 & 0 & 8 \\
\hline
\end{tabular}




\begin{tabular}{|c|c|c|c|c|c|c|c|c|}
\hline \multirow[t]{2}{*}{ Species name } & \multirow[t]{2}{*}{ Family } & \multirow{2}{*}{$\begin{array}{l}\text { Fruit } \\
\text { size } \\
(\mathrm{mm})\end{array}$} & \multirow{2}{*}{$\begin{array}{l}\text { Fruit } \\
\text { color }\end{array}$} & \multirow{2}{*}{$\begin{array}{l}\text { Mode of } \\
\text { seed } \\
\text { dispersal }\end{array}$} & \multirow[t]{2}{*}{ Habitat } & \multicolumn{3}{|c|}{ No. of seedlings } \\
\hline & & & & & & Fn & $B f$ & Open \\
\hline $\begin{array}{l}\text { Diospyros } \\
\text { whyteana(Hiern) F.White }\end{array}$ & Ebenaceae & $20 \times 20$ & red & animal & forest & 14 & 1 & 0 \\
\hline $\begin{array}{l}\text { Euclea racemosassp. schimperi (A. } \\
\text { DC.) F. White }\end{array}$ & Ebenaceae & 10 in dia. & red & animal & for./woodl. & 2 & 0 & 0 \\
\hline $\begin{array}{l}\text { Erica benguelensis(Welw. ex Engl.) } \\
\text { E.G.H. Oliv. }{ }^{\text {a }}\end{array}$ & Ericaceae & unknown & unknown & unknown & woodland & 0 & 0 & 5 \\
\hline $\begin{array}{l}\text { Croton macrostachyusHochst. ex } \\
\text { Delile }^{d}\end{array}$ & Euphorbiaceae & 5 in dia. & green & animal & for./woodl. & 3 & 0 & 0 \\
\hline Aeschynomene schliebeniiHarms ${ }^{a}$ & Fabaceae & - & - & unknown & woodland & 0 & 13 & 13 \\
\hline Erythrina abyssinica Lam. ${ }^{a}$ & Fabaceae & - & - & explosive & woodland & 2 & 0 & 0 \\
\hline Scolopia sp. & Flacourtiaceae & unknown & unknown & unknown & unknown & 2 & 0 & 0 \\
\hline Psorospermum febrifugumSpach & Hypericaceae & $7 \times 7$ & red & animal & woodland & 1 & 0 & 2 \\
\hline Apodytes dimidiata E.Mey. ex Arn. ${ }^{c}$ & Icacinaceae & 10 in dia. & black & animal & forest & 16 & 0 & 0 \\
\hline Grewia stolziiUlbr.c & Malvaceae & 30 in dia. & unknown & animal & forest & 0 & 1 & 0 \\
\hline $\begin{array}{l}\text { Dissotis } \\
\text { johnstoniana var.johnstonianaBenth. }\end{array}$ & Melastomataceae & unknown & unknown & unknown & woodland & 22 & 1 & 0 \\
\hline Trichilia emetica $V a h l^{\mathrm{e}}$ & Meliaceae & $20 \times 10$ & red & animal & for./woodl. & 4 & 0 & 0 \\
\hline
\end{tabular}




\begin{tabular}{|c|c|c|c|c|c|c|c|c|}
\hline \multirow[t]{2}{*}{ Species name } & \multirow[t]{2}{*}{ Family } & \multirow{2}{*}{$\begin{array}{l}\text { Fruit } \\
\text { size } \\
(\mathrm{mm})\end{array}$} & \multirow{2}{*}{$\begin{array}{l}\text { Fruit } \\
\text { color }\end{array}$} & \multirow{2}{*}{$\begin{array}{l}\text { Mode of } \\
\text { seed } \\
\text { dispersal }\end{array}$} & \multirow[t]{2}{*}{ Habitat } & \multicolumn{3}{|c|}{ No. of seedlings } \\
\hline & & & & & & Fn & $B f$ & Open \\
\hline $\begin{array}{l}\text { Bersama } \\
\text { abyssinica var.engleriana(Gürke) F. } \\
\text { White }^{\text {a }}\end{array}$ & Melianthaceae & $10 \times 8$ & red & animal & for./woodl. & 1 & 1 & 0 \\
\hline Rapanea melanophloeos(L.) Mez ${ }^{\mathrm{d}}$ & Myrsinaceae & $8 \times 8$ & purple & animal & for./woodl. & 2 & 0 & 0 \\
\hline $\begin{array}{l}\text { Syzygium } \\
\text { guineense ssp.afromontanum } \\
\text { F. White }{ }^{c}\end{array}$ & Myrtaceae & $16 \times 14$ & purple & animal & forest & 36 & 2 & 0 \\
\hline Ochna schweinfurthianaF. Hoffm. ${ }^{a}$ & Ochnaceae & $7 \times 6$ & black & animal & woodland & 0 & 1 & 0 \\
\hline Schrebera alata(Hochst.) Welw. ${ }^{c}$ & Oleaceae & - & - & explosive & forest & 3 & 0 & 0 \\
\hline Uapaca kirkianaMüll. Arg. ${ }^{a}$ & Phyllanthaceae & $25 \times 24$ & yellow & animal & woodland & 0 & 10 & 5 \\
\hline Bridelia bridelifolia (Pax) Fedde ${ }^{a}$ & Phyllanthaceae & $8 \times 7$ & black & animal & for./woodl. & 6 & 5 & 0 \\
\hline Faurea speciousaWelw. ${ }^{a}$ & Proteaceae & - & - & wind & woodland & 3 & 3 & 5 \\
\hline Protea angolensisWelw. ${ }^{\mathrm{a}}$ & Proteaceae & - & - & wind & woodland & 0 & 0 & 6 \\
\hline $\begin{array}{l}\text { Protea petiolaris(Hiern) Baker \& C.H. } \\
\text { Wright }^{\mathrm{a}}\end{array}$ & Proteaceae & - & - & wind & woodland & 0 & 0 & 1 \\
\hline Prunus africana (Hook. f.)Kalkman ${ }^{c}$ & Rosaceae & $10 \times 7$ & brown & animal & forest & 13 & 0 & 0 \\
\hline Oxyanthus & Rubiaceae & 30 in dia. & yellow & animal & forest & 2 & 0 & 0 \\
\hline
\end{tabular}




\begin{tabular}{|c|c|c|c|c|c|c|c|c|}
\hline \multirow[t]{2}{*}{ Species name } & \multirow[t]{2}{*}{ Family } & \multirow{2}{*}{$\begin{array}{l}\text { Fruit } \\
\text { size } \\
(\mathrm{mm})\end{array}$} & \multirow{2}{*}{$\begin{array}{l}\text { Fruit } \\
\text { color }\end{array}$} & \multirow{2}{*}{$\begin{array}{c}\text { Mode of } \\
\text { seed } \\
\text { dispersal }\end{array}$} & \multirow[t]{2}{*}{ Habitat } & \multicolumn{3}{|c|}{ No. of seedlings } \\
\hline & & & & & & Fn & $B f$ & Open \\
\hline $\begin{array}{l}\text { speciosus spp.stenocarpus (K. } \\
\text { Schum.) Bridson }{ }^{c}\end{array}$ & & & & & & & & \\
\hline $\begin{array}{l}\text { Psydrax schimperiana(A.Rich.) } \\
\text { Bridson' }\end{array}$ & Rubiaceae & 10 in dia. & black & animal & forest & 4 & 0 & 0 \\
\hline Allophylus chaunostachysGilgc & Sapindaceae & 6 in dia. & red & animal & for./woodll. & 6 & 0 & 0 \\
\hline unknown 1 & & & & & & 2 & 12 & 0 \\
\hline unknown 2 & & & & & & 2 & 1 & 0 \\
\hline
\end{tabular}

Fn, under Ficus natalensis; Bf, under Brachystegia floribunda; Open, open microsites for., forest; woodl., woodland; dia., diameter. Significant indicator species for $F$. natalensis sites are in bold type.

aCoutes Palgrave (2002).

'Flora Zambesiaca.

'White et al., 2001.

dFriis (1992).

'Van wyk and Van Wyk (1997). 


\subsection{Seed rain}

Sixty-seven seeds of $S$. guineense ssp. afromontanum were found. The rate of seed deposition differed significantly among microsites (Fig. 3). Most dispersed seeds (85\%) were found under F. natalensis. The number of dispersed seeds was significantly higher under F. natalensis than in the other two microsites. Dispersed seeds of S. guineense ssp. afromontanum were found under all eight F.natalensis individuals.

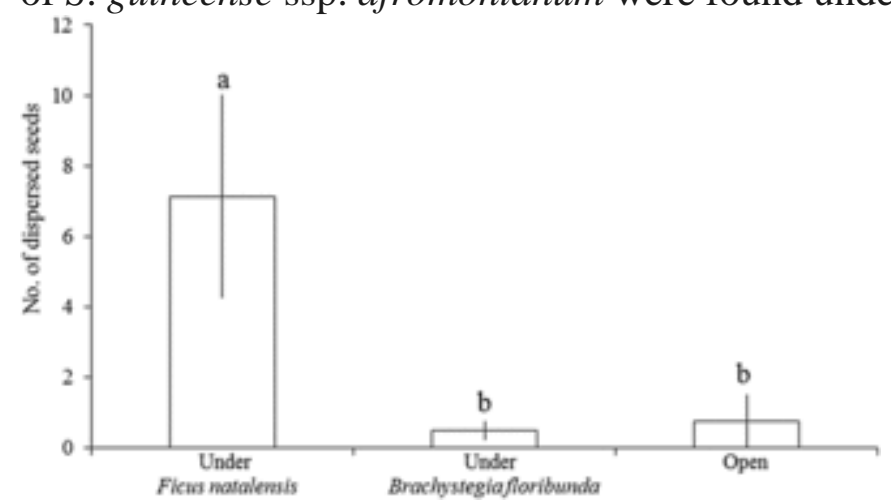

Fig. 3 Mean number ( \pm SE) of Syzygium guineense ssp. afromontanum seeds dispersed at three microsites in a miombo woodland in northern Malawi. The seed rain was monitored from January to March 2012. Means with the same lower case letters are not significantly different ( $P>0.05$; Tukey's post hoc test) among microsites.

\subsection{Animal visits to $F$. natalensis}

During $80 \mathrm{~h}$ of focal observations, I observed 21 bird and 1 mammal species at F. natalensis, of which 10 species were frugivores (Table A.1). Seven of the frugivore species were species that primarily use forest habitat. These accounted for $52 \%$ of all visiting animals. The two most abundant forest-related frugivores were sun squirrels (0.6 counts/h) and Schalow's turacos ( 0.4 counts/h). 
Table A.1 Animal visiting fruiting Ficus natalensistrees in a miombo woodland in northern Malawi, their body masses, diets, habitats, observed behaviors, numbers of visits (n), and visit durations (total and median).

\begin{tabular}{|c|c|c|c|c|c|c|c|c|}
\hline Name & & $\begin{array}{l}\text { Body } \\
\text { mass } \\
\text { (g) }\end{array}$ & Diet & Habitat & $\begin{array}{l}\text { Observed } \\
\text { behavior }\end{array}$ & $\begin{array}{l}\text { Visits } \\
\text { (n) }\end{array}$ & $\begin{array}{l}\text { Total } \\
\text { duration } \\
\text { (min) }\end{array}$ & $\begin{array}{c}\text { Median } \\
\text { duration } \\
\text { (min) }\end{array}$ \\
\hline \multicolumn{9}{|l|}{ Birds } \\
\hline $\begin{array}{l}\text { Columba } \\
\text { arquatrix (Temminck) }\end{array}$ & African olive pigeon & $\begin{array}{l}300- \\
480\end{array}$ & Frugivore & Forest & Perching & 3 & 13.6 & 4.2 \\
\hline 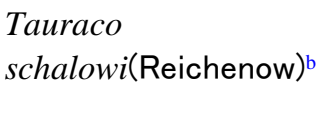 & Schalow's turaco & $\begin{array}{l}210- \\
270\end{array}$ & Frugivore & Forest/Woodland & $\begin{array}{l}\text { Foraging } \\
\text { for } \\
\text { syconium }\end{array}$ & 29 & 121.1 & 3.7 \\
\hline $\begin{array}{l}\text { Treron } \\
\text { calva }\left(\text { Temminck) }^{a}\right.\end{array}$ & $\begin{array}{l}\text { Afrcan green } \\
\text { pigeon }\end{array}$ & $\begin{array}{l}210- \\
250\end{array}$ & Frugivore & Woodland & $\begin{array}{l}\text { Foraging } \\
\text { for } \\
\text { syconium }\end{array}$ & 2 & 5.5 & 2.8 \\
\hline $\begin{array}{l}\text { Onychognathus } \\
\text { morio(Linnaeus)c }\end{array}$ & $\begin{array}{l}\text { Red-winged } \\
\text { starling }\end{array}$ & $\begin{array}{l}120- \\
155\end{array}$ & Frugivore & Woodland & Perching & 1 & 5.4 & 5.4 \\
\hline $\begin{array}{l}\text { Malaconotus } \\
\text { blanchotiStephens }{ }^{c}\end{array}$ & $\begin{array}{l}\text { Grey-headed } \\
\text { bush-shrike }\end{array}$ & $\begin{array}{l}65- \\
95\end{array}$ & Non-frugivore & Woodland & $\begin{array}{l}\text { Foraging } \\
\text { for insect }\end{array}$ & 2 & 1.1 & 0.6 \\
\hline $\begin{array}{l}\text { Turdus } \\
\text { libonyana(Smith)d }\end{array}$ & Kurrichane thrush & $\begin{array}{l}50- \\
70\end{array}$ & Frugivore & Woodland & $\begin{array}{l}\text { Foraging } \\
\text { for } \\
\text { syconium }\end{array}$ & 22 & 64.7 & 1.4 \\
\hline $\begin{array}{l}\text { Pycnonotus } \\
\text { tricolor(Hartlaub) }\end{array}$ & Dark-capped bulbul & $\begin{array}{l}30- \\
48\end{array}$ & Frugivore & Forest/Woodland & $\begin{array}{l}\text { Foraging } \\
\text { for }\end{array}$ & 3 & 4.7 & 1.6 \\
\hline
\end{tabular}




\begin{tabular}{|c|c|c|c|c|c|c|c|c|}
\hline & & & & & syconium & & & \\
\hline $\begin{array}{l}\text { Chrysococcyx } \\
\text { caprius(Boddaert) }^{\mathrm{b}}\end{array}$ & Diderick cuckoo & $\begin{array}{l}22- \\
42\end{array}$ & Non-frugivore & Woodland & $\begin{array}{l}\text { Foraging } \\
\text { for insect }\end{array}$ & 1 & 0.3 & 0.3 \\
\hline $\begin{array}{l}\text { Muscicapa } \\
\text { caerulescens(Hartlaub)a }\end{array}$ & Ashy flycatcher & $\begin{array}{l}15- \\
17\end{array}$ & Frugivore & Forest/Woodland & $\begin{array}{l}\text { Foraging } \\
\text { for insect }\end{array}$ & 12 & 13.2 & 0.7 \\
\hline $\begin{array}{l}\text { Chalcomitra } \\
\text { amethystina(Shaw) }\end{array}$ & Amethyst sunbird & $\begin{array}{l}11- \\
19\end{array}$ & Non-frugivore & Forest/Woodland & $\begin{array}{l}\text { Foraging } \\
\text { for } \\
\text { syconium }\end{array}$ & 1 & 7.1 & 7.1 \\
\hline $\begin{array}{l}\text { Ficedula } \\
\text { albicollis(Temminck)e }\end{array}$ & Collared flycatcher & $\begin{array}{l}10- \\
14\end{array}$ & Non-frugivore & Woodland & $\begin{array}{l}\text { Foraging } \\
\text { for insect }\end{array}$ & 47 & 53.8 & 0.9 \\
\hline 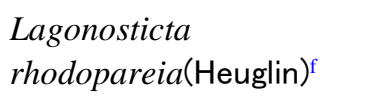 & Jameson's firefinch & $8-13$ & Non-frugivore & Woodland & Perching & 1 & 0.5 & 0.5 \\
\hline $\begin{array}{l}\text { Zosterops } \\
\text { senegalensis(Bonaparte)c }\end{array}$ & $\begin{array}{l}\text { African yellow } \\
\text { white-eye }\end{array}$ & $8-11$ & Frugivore & Forest/Woodland & $\begin{array}{l}\text { Foraging } \\
\text { for } \\
\text { syconium }\end{array}$ & 1 & 0.4 & 0.4 \\
\hline
\end{tabular}




\begin{tabular}{|c|c|c|c|c|c|c|c|c|}
\hline Name & & $\begin{array}{l}\text { Body } \\
\text { mass } \\
(\mathrm{g})\end{array}$ & Diet & Habitat & $\begin{array}{l}\text { Observed } \\
\text { behavior }\end{array}$ & $\begin{array}{l}\text { Visits } \\
(n)\end{array}$ & $\begin{array}{l}\text { Total } \\
\text { duration } \\
\text { (min) }\end{array}$ & $\begin{array}{c}\text { Median } \\
\text { duration } \\
\text { (min) }\end{array}$ \\
\hline $\begin{array}{l}\text { Phylloscopus } \\
\text { trochilus(Linnaeus)a }\end{array}$ & Willow warbler & $7-12$ & Non-frugivore & Forest/Woodland & Perching & 1 & 1.2 & 1.2 \\
\hline $\begin{array}{l}\text { Hedydipna } \\
\text { collaris(Vieillot) }\end{array}$ & Collared sunbird & $6-11$ & Frugivore & Forest/Woodland & Perching & 1 & 0.2 & 0.2 \\
\hline $\begin{array}{l}\text { Cinnyris } \\
\text { venustus(Shaw) }\end{array}$ & Variable sunbird & $6-10$ & Non-frugivore & Forest/Woodland & Perching & 1 & 1.5 & 1.5 \\
\hline unidentified bird 1 & & & & & $\begin{array}{l}\text { Foraging } \\
\text { for } \\
\text { syconium }\end{array}$ & 4 & 5.5 & 1.3 \\
\hline unidentified bird 2 & & & & & $\begin{array}{l}\text { Foraging } \\
\text { for } \\
\text { syconium }\end{array}$ & 1 & 3.1 & 3.1 \\
\hline unidentified bird 3 & & & & & Perching & 1 & 1.4 & 1.4 \\
\hline \multicolumn{9}{|l|}{ Mammal } \\
\hline $\begin{array}{l}\text { Heliosciurus } \\
\text { mutabilis(Peters)s }\end{array}$ & Sun squirrel & 400 & Frugivore & Forest/Woodland & $\begin{array}{l}\text { Foraging } \\
\text { for } \\
\text { syconium }\end{array}$ & 48 & 850.2 & 14.7 \\
\hline
\end{tabular}

${ }^{a}$ Fry et al. (1988).

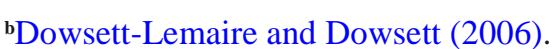


'Fry and Keith (1988).

dKeith et al. (1992).

eUrban et al. (1997).

fFry et al. (2004).

sKingdon (1974). 


\section{Discussion}

\subsection{Ficus natalensis and $B$}

floribunda provided conditions for the establishment of forest species that were similar to one another and better than those in the open sites (Table 1). Indeed, the survival of S. guineense ssp. afromontanum seedlings under F.natalensis and B. floribunda was similar, and seedling survival under these trees was significantly higher than that in open sites (Fig. 1). In contrast, the composition of naturally recruiting seedling communities differed significantly under F. natalensis and B. floribunda (Fig. 2). I attribute this result to the perch effect provided by F. natalensis, which promoted seed deposition by frugivorous birds. Most seedlings under F. natalensis are reported to have small, brightly colored diaspores, suggesting bird dispersal (Table 2). Seed deposition of S.guineense ssp. afromontanum under F. natalensis was much higher compared toB. floribunda or open sites (Fig. 3). Furthermore, forest-related frugivores were observed frequently visiting fruiting $F$. natalensis (Table A1). These results support the importance of the perch effect provided by F. natalensis for nucleation.

Few studies have demonstrated the role of tree perches in the nucleation process separately from the role of the facilitative effect. Pausas et al. (2006) identified the importance of the perch effect on nucleation in Mediterranean abandoned fields when making a comparison of seedling distributions between fleshy fruit species and non-fleshy fruit species. The seedlings of fleshy fruit species were positively associated with shrubs, while seedlings of non-fleshy fruit species were randomly distributed (Pausas et al., 2006). My quantitative comparisons of the establishment of forest tree species under fleshy fruit versus non-fleshy fruit trees demonstrate the importance of species-specific interactions in seed deposition during the early stages of nucleation in sparse open woodlands of southeastern Africa.

Overlapping fruiting seasons among plants that share seed dispersal agents can enhance the seed dispersal of exotic plant species during the invasive process (Battaglia et al., 2009; White and Vivian-Smith, 2011) and may promote the process of mistletoe infection of host trees (Carlo and Aukema, 2005). White and Vivian-Smith (2011), for example, demonstrated that the seed rain of exotic species was substantially higher under synchronously fruiting crowns than under non-fruiting crowns. A similar mechanism may operate during the spread of forests into sparse open vegetation. Although Ficus trees are generally known to exhibit inter-tree asynchrony in syconia 
production (Shanahan et al., 2001), F.natalensis has two peaks of ripening each year (in August-October and in January-April; Dowsett-Lemaire, 1985). These peaks of syconia maturation partially overlap with fruit set in montane rainforests in this region (Dowsett-Lemaire, 1985). Thus, the timing of fruit ripening in F. natalensis may drive the observed pattern of forest tree establishment under F. natalensis in miombo woodland. Future studies should determine whether the timing of fruit maturation in nuclei trees promotes the nucleation process in sparse open vegetation.

Individual animal species are likely to vary in their contribution to the seed deposition of animal-dispersed forest species under $F$. natalensis, depending on their diet, handling behavior, and habitat dependency (Kitamura et al., 2002; Lehouck et al., 2009). Among the animals observed here, Schalow's turaco is likely to be an important disperser of forest species in miombo woodland because it consumes a wide range of fruits in montane rainforests and can swallow fruits up to $30 \mathrm{~mm}$ in diameter (Dowsett-Lemaire, 1988). Although Schalow's turacos prefer forest habitats (Fry and Keith, 1988), they are not biome-restricted (Mills et al., 2008). In fact, Schalow's turacos were frequently observed visiting fruitingF. natalensis in miombo woodland (Table A1). Other forest-related frugivores, such as African green pigeons and dark-capped bulbuls, recorded during observations may also contribute to forest seed transport, especially for small-seeded species.

Although I have highlighted the importance of the perch effect so far, my results do not reject the importance of a facilitative effect as a driver of nucleation. Seedling survival of $S$. guineense ssp. afromontanum in open sites was nearly sixfold lower than under F. natalensis (Fig. 1). This result indicates that seedlings of forest species cannot persist without the facilitative effect of nearby trees in miombo woodland.

Shade provided by tree crowns may protect seedlings from desiccation (Gomez et al., 2005). The lower air temperature and solar radiation, and higher air humidity measured under F. natalensis crowns in comparison with open areas can reduce leaf temperature and transpiration losses, creating a more favorable water balance for forest tree seedlings, even in the absence of microsite differences in soil water content (as observed by Gomez et al., 2005). In addition, because grass cover is lower under F. natalensis compared to open sites, seedling survival can be facilitated by reduced competition with grass and the suppressed occurrence of fire (Shararn et al., 2009; Hoffmann et al., 2012b; Salazar et al., 2012). This array of modifications under the F. natalensis crown could result in higher establishment of forest species under the stressful environmental conditions found in miombo woodland. 
Syzygium guineense ssp. afromontanum seeding survival was also enhanced under B. floribunda (Fig. 1), where environmental conditions are ameliorated in the same way as under F. natalensis (Table 1). However, I found little seedling establishment of forest species under $B$. floribunda (Table 2), likely because of seed limitation (i.e., seeds did not reach suitable habitats). The seed rain monitoring measurements detected few S.guineense ssp. afromontanumseed arrivals under B. floribunda canopy (Fig. 3), an observation that supports my suggestion. Thus, in agreement with recent interpretations by Reid and Holl (2013), my findings indicate that trees will most likely act as nuclei when they facilitate seedling establishment and promote seed deposition.

This study shows that $F$. natalensis is an efficient nucleus during the nucleation process in miombo woodlands because it promotes seed deposition of animal-dispersed forest species and facilitates seedling establishment. However, the presence of F. natalensis may have negative effects on some other demographic stages. For example, seed predation is generally high under crowns compared to open microsites because rodents prefer to forage under trees where they experience lower predation risk (Smit et al., 2008). Thus, it is important to examine all demographic stages of recruitment, from seed arrival to seedling survival and growth, to fully evaluate the role of nuclei trees.

\section{Conclusions}

This is one of the very few studies to separately evaluate the importance of the perch and facilitative effects on the nucleation process. It was found that the perch effect increased seed deposition by frugivorous birds, and was a prerequisite for forest nucleation in areas of open vegetation. Furthermore, I demonstrated that the amelioration of microhabitat conditions in the vicinity of trees also significantly affects the dynamics of the nucleation process. Thus, the study suggests that trees drive the nucleation process when they promote seed deposition and have positive effects on the post-dispersal stages of plant recruits.

\section{Acknowledgments}

G. Yamakoshi, K. Zamma, S. Ichino, K. Mizuno and two anonymous reviewers are acknowledged for their constructive criticism of earlier drafts of this manuscript. This study enjoyed logistic support from the Forestry Research Institute of Malawi and 
the National Herbarium and Botanical Gardens of Malawi. I would like to thank T. Chanyenga for his kind support and $\mathrm{H}$. Patel for identification of plant specimens. This research was funded by the Japan Societyfor the Promotion of Science Global COE Programme (E-04): In Search of a Sustainable Humanosphere in Asia and Africa.

\section{References}

Albornoz F.E., Gaxiola A., Seaman B.J., Pugnaire F.I. and Armesto J.J.,Nucleation-driv en regeneration promotes post-fire recovery in a Chilean temperate forest, Plant Ecol. 214, 2013, 765-776.

Arantes C.d.S., do Vale V.S., de Oliveira A.P., do Prado Junior J.A., Lopes S.D.F.and Schiavini I., Forest species colonizing cerrado open areas: distance and area effects on the nucleation process, Braz. $J$.

Bot. 37, 2014, 143-150.

Battaglia L.L., Denslow J.S., Inczauskis J.R. and Baer S.G., Effects of native vegetation on invasion success of Chinese tallow in a floating marsh ecosystem, J. Ecol. 97, 2009, 239-246.

Bowman D.M.J.S., Murphy B.P. and Banfai D.S., Has global environmental change caused monsoon rainforests to expand in the Australian monsoon tropics?, Landsc. Ecol. 25, 2010, 1247-1260.

Campbell B., Frost P. and Byron N., Miombo woodlands and their use: overview and key issues, In: Campbell B., (Ed), The Miombo in Transition: Woodlands and Welfare in Africa, 1996, Center for International Forestry Research; Bogor, 1-5.

Carlo T.A. and Aukema J.E., Female-directed dispersal and facilitation between a tropical mistletoe and a dioecious host, Ecology 86, 2005, 3245-3251.

Carlucci M.B., Duarte L.D. and Pillar V.D., Nurse rocks influence forest expansion over native grassland in southern Brazil, J. Veg. Sci. 22, 2011, 111-119.

Chapman J.D., PART II description of the forest, In: Chapman J.D. and White F.,(Eds.), The Evergreen Forests of Malawi, 1970, Commonwealth Forestry Institute; Oxford, 113-180.

Chidumayo E. and Frost P., Population biology of miombo woodland, In:Campbell B., (Ed), The Miombo in Transition: Woodlands and Welfare in Africa, 1996, Center for International Forestry Research; Bogor, 59-72.

Corbin J.D. and Holl K.D., Applied nucleation as a forest restoration strategy, For. Ecol. Manage 265, 2012, 37-46. 
Dowsett-Lemaire F., The forest vegetation of the Nyika Plateau (Malawi-Zambia): ecological and phenological studies, Bull. Jard. Bot. Natl. Belg 55, 1985,301-392.

Dowsett-Lemaire F., Fruit choice and seed dissemination by birds and mammals in the evergreen forests of upland Malawi, Rev. d'Ecologie 43, 1988,251-285.

Dowsett-Lemaire F. and Dowsett R.J., The Birds of Malawi: an Atlas and Handbook, 2006, Tauraco Press and Aves; Liege.

Duarte L.D., Carlucci M.B., Hartz S.M. and Pillar V.D., Plant dispersal strategies and the colonization of Araucaria forest patches in a grassland-forest mosaic, J. Veg. Sci. 18, 2007, 847-858.

Duarte L.D.S., Dos-Santos M.M.G., Hartz S.M. and Pillar V.D., Role of nurse plants in Araucaria Forest expansion over grassland in south Brazil, Austral Ecol. 31, 2006, 520-528.

Dufrêne M. and Legendre P., Species assemblages and indicator species: the need for a flexible asymmetrical approach, Ecol. Monogr. 67, 1997, 345-366.

Ekblom A., Forest-savanna dynamics in the coastal lowland of southern Mozambique since c. AD1400, Holocene 18, 2008, 1247-1257.

Favier C., De Namur C. and Dubois M.-A., Forest progression modes in littoral Congo, central atlantic Africa, J. Biogeogr. 31, 2004, 1445-1461.

Frazer G.W., Canham C.D. and Lertzman K.P., Gap Light Analyzer (GLA) 2.0: Imaging Software to Extract Canopy Structure and Gap Light Transmission Indices from True-colour Fisheye Photographs, 1999, Simon Fraser University; Burnaby.

Friis I., Forests Types and Forest Trees of Northeast Tropical Africa, 1992, Royal Botanic Gardens Kew; London.

Fry C.H. and Keith S., The Birds of Africa. Volume VI, 1988, Academic Press; New York.

Fry C.H., Keith S. and Urban E.K., The Birds of Africa. Volume III, 1988,Academic Press; New York.

Fry C.H., Keith S., Woodcock M. and Willis I., The Birds of Africa. Volume VII,2004, Academic Press; New York.

Fujita T., Ficus natalensis facilitates the establishment of a montane rain-forest tree in south-east African tropical woodlands, J. Trop. Ecol. 30, 2014,303-310.

Fujita T. and Mizuno K., Role of nurse rocks on woody plant establishment in a South African grassland, TROPICS 24, 2015, 57-64. 
Gomez J.M., Zamora R. and Boettinger J.L., Canopy vs. soil effects of shrubs facilitating tree seedlings in Mediterranean montane ecosystems, J. Veg. Sci. 16, 2005, 191-198.

Hoffmann W.A., Geiger E.L., Gotsch S.G., Rossatto D.R., Silva L.C.R., Lau O.L.,Harid asan M. and Franco A.C., Ecological thresholds at the savanna-forest boundary: how plant traits, resources and fire govern the distribution of tropical biomes, Ecol. Lett. 15, 2012a, 759-768.

Hoffmann W.A., Jaconis S.Y., Mckinley K.L., Geiger E.L., Gotsch S.G. and FrancoA.C ., Fuels or microclimate? Understanding the drivers of fire feedbacks at savannaforest boundaries, Austral Ecol. 37, 2012b, 634-643.

Keith S., Urban E.K. and Fry C.H., The Birds of Africa. Volume IV, 1992,Academic Press; New York.

Kingdon J., East African Mammals. Volume IIB, 1974, The University of Chicago Press; Chicago.

Kitamura S., Yumoto T., Poonswad P., Chuailua P., Plongmai K., Maruhashi T.and No ma N., Interactions between fleshy fruits and frugivores in a tropical seasonal forest in Thailand, Oecologia 133, 2002, 559-572.

Lehouck V., Spanhove T., Colson L., Adringa-Davis A., Cordeiro N.J. and Lens L.,Hab itat disturbance reduces seed dispersal of a forest interior tree in a fragmented African cloud forest, Oikos 118, 2009, 1023-1034.

McCarthy T., Ellery W. and Dangerfield J., The role of biota in the initiation and growth of islands on the floodplain of the Okavango alluvial fan, Botswana,Earth Surf. Process. Landf. 23, 1998, 291-316.

Mills M.S.L., vaz Pinto P. and Dean W.R.J., The avifauna of Cangandala National Park, Angola, Bull. Afr. Bird Club 15, 2008, 113-120.

Mitchard E.T.A., Saatchi S.S., Gerard F.F., Lewis S.L. and Meir P., Measuring woody encroachment along a forest-savanna boundary in central Africa,Earth Interact. 13, 2009, 1-29.

Pausas J.G., Bonet A., Maestre F.T. and Climent A., The role of the perch effect on the nucleation process in Mediterranean semi-arid oldfields, Acta Oecol 29, 2006, 346352.

Puyravaud J.-P., Dufour C. and Aravajy S., Rain forest expansion mediated by successional processes in vegetation thickets in the Western Ghats of India,J. Biogeogr. 30, 2003, 1067-1080.

Reid J.L. and Holl K.D., Arrival $\neq$ survival, Restor. Ecol. 21, 2013, 153-155. 
Salazar A., Goldstein G., Franco A.C. and Miralles-Wilhelm F., Differential seedling establishment of woody plants along a tree density gradient in Neotropical savannas, J. Ecol. 100, 2012, 1411-1421.

Schlawin J.R. and Zahawi R.A., 'Nucleating' succession in recovering neotropical wet forests: the legacy of remnant trees, J. Veg. Sci. 19, 2008, 485-492.

Shanahan M., So S., Compton S.G. and Corlett R., Fig-eating by vertebrate frugivores: a global review, Biol. Rev. Camb. Philos. Soc. 76, 2001, 529-572.

Shararn G.J., Sinclair A.R.E., Turkington R. and Jacob A.L., The savanna treeAcacia polyacantha facilitates the establishment of riparian forests in Serengeti National Park, Tanzania, J. Trop. Ecol. 25, 2009, 31-40.

Slocum M.G., How tree species differ as recruitment foci in a tropical pasture,Ecology 82, 2001, 2547-2559.

Slocum M.G. and Horvitz C.C., Seed arrival under different genera of trees in a neotropical pasture, Plant Ecol. 149, 2000, 51-62.

Smit C., den Ouden J. and Díaz M., Facilitation of Quercus ilex recruitment by shrubs in Mediterranean open woodlands, J. Veg. Sci. 19, 2008, 193-200.

Urban E.K., Fry C.H. and Keith S., The Birds of Africa. Volume V, 1997, Academic Press; New York.

Vieira I.R., de Araújo F.S. and Zandavalli R.B., Shrubs promote nucleation in the Brazilian semi-arid region, J. Arid. Environ. 92, 2013, 42-45.

Vincens A., Williamson D., Thevenon F., Taieb M., Buchet G., Decobert M. andThouv eny N., Pollen-based vegetation changes in southern Tanzania during the last 4200 years: climate change and/or human impact, Palaeogeogr. Palaeoclimatol.

Palaeoecol. 198, 2003, 321-334.

White F., Dowsett-Lemaire F. and Chapman J.D., Evergreen Forest Flora of Malawi, 2001, Royal Botanic Gardens; London.

White E. and Vivian-Smith G., Contagious dispersal of seeds of synchronously fruiting species beneath invasive and native fleshy-fruited trees, Austral Ecol. 36, 2011, 195-202.

Yarranton G. and Morrison R., Spatial dynamics of a primary succession: nucleation, J. Ecol. 62, 1974, 417-428.

Zahawi R.A., Holl K.D., Cole R.J. and Reid J.L., Testing applied nucleation as a strategy to facilitate tropical forest recovery, J. Appl. Ecol. 50, 2013, 88-96 